Article

\title{
The Concern about Biodiversity as a Criterion for the Classification of the Sustainable Consumer: A Cross- Cultural Approach
}

\author{
Eva M. Murgado-Armenteros ${ }^{\mathbb{D}}$, María Gutierrez-Salcedo * ${ }^{\mathbb{D}}$ and Francisco José Torres-Ruiz \\ Department of Management, Marketing and Sociology, University of Jaen, 23071 Jaen, Spain; \\ emurgado@ujaen.es (E.M.M.-A.); ftorres@ujaen.es (F.J.T.-R.) \\ * Correspondence: msalcedo@ujaen.es
}

Received: 9 March 2020; Accepted: 22 April 2020; Published: 24 April 2020

\begin{abstract}
One of the variables assessed in the research related to the consumption of green products is environmental concern. This work explores a new dimension to environmental concern: biodiversity. The reasons why research has focused on the mentioned dimension are, on one hand, the consideration of biodiversity as the main environmental indicator of the sustainability and, on the other, the paucity of marketing studies analyzing this variable and its relationship with the purchase behavior of sustainable products. The present paper proposes a classification of sustainable consumers according to their level of biodiversity concern. It is based on a quantitative study on the consumption behavior of olive oils carried out in four European countries, using the clustering multivariate technique. The results point out that there are differences between the segments depending on their level of commitment to biodiversity. The country's influence on the way that its people experience biodiversity was also tackled. As a main conclusion, we identify four clusters or segments (not concerned, passive, active and influencers), setting up a multilevel structure of ascending intensity with regard to their level of biodiversity concern, with differences in the composition according to age and sex between countries.
\end{abstract}

Keywords: biodiversity; environmental concern; sustainable consumer; cross-cultural; olive oils

\section{Introduction}

Since the 1970s, nature conservation has increased its importance as a specific value in consumption decisions, which has translated into a growing social interest and a large number of academic works. Many of these works have been developed under a marketing approach, with the final objective of knowing, understanding and explaining the behavior of consumers in relation to the environment, as a way to conceive effective strategies to develop sustainable behaviors [1,2].

Within this body of literature, some studies have focused on the study of the demographic characteristics of the consumer, especially gender [3-5]. Others have created scales to describe consumer segments based on environmental problems [6]. Some have examined the impact of ecological factors on the intention to purchase green products, such as environmental knowledge $[4,7]$, environmental awareness [8-12], the attitude towards the environment [11,13], or ecology as a heuristic of superiority [14-16]. Health factors have been another set of variables that have pushed the green consumption, including concerns about food security and health awareness $[17,18]$. Various studies have examined the cultural values of the person, such as selfishness, ability, attitude towards the purchase of green products, individualism/collectivism [10,17,19-22]. Lastly, several works have analyzed the influence of ethical variables on food-purchasing intent and behavior, including moral concern, moral attitude, ethical reasons, ethical obligations and ethical judgments [23-27]. In an effort 
to synthesis, all these works can be considered as nuances, extensions or factors related to a core element: the consumption of organic products. All of them offer strategies and recommendations to improve the consumption, generally linked to communication and awareness campaigns. However, it is not the only element that allows us to define sustainable consumers.

Several authors have pointed to environmental concern, defined as a strong attitude towards the preservation of the environment [28], as one of the main factors influencing sustainable purchasing behavior [29-32], that can be used as a criteria in the segmentation or characterization of green consumers [33].

Based on the definitions of environmental concern proposed by Dunlap et al. [34] and Arroyo et al. [35], it is reasonable to argue that the degree to which an individual is concerned about environmental problems and recognizes the need to address them can influence their sustainable buying behavior in different ways. That is, consumers with a high degree of concern for the environment will have different sustainable purchase behavior-understood as being "greener" — than those with a lower degree of concern.

However, the literature that analyzes the environmental concern in relation to the purchase behavior shows contradictory results. Although there is evidence that the increase in environmental concern has a positive effect on behavior [29-31], it is not possible to establish an exact conclusion about actual purchase behavior.

Several studies have shown that environmental concern has a significant impact on the predisposition to buy green products [36-40]. Other authors pointed out that consumers concerned about the environment have more positive attitudes towards organic food [41-44] and buy more organic products [45]. Specifically, Ting et al. [46] and Chen and Tung [47] suggested that environmental concern has a significant positive effect on the desire intention to stay in green hotels, while Sang and Bekhet [48] concluded that consumers concerned about environmental problems are more willing to buy electric vehicles. Other studies have highlighted that consumers with greater environmental concern tend to have a more positive environmental attitude, which in turn increases their willingness to act [49-51].

However, in other cases, this link does not exist and the lack of coherence between the environmental concern of consumers and their buying decisions is evident [52,53]. Specifically, Malik et al. [54] concluded that although there is a positive relationship between awareness and the development of environmental concern, the latter is not enough to predict the buying behavior of green products.

Some possible causes that can explain the gap between environmental concern and the consumption in the case of organic food are a clear lack of knowledge of the characteristics of these products, distribution problems, overpricing and even a fictitious attitude, in the sense that people say they are more concerned about the environment-motivated by the social pressure-than they really are.

The present paper explores a new perspective of environmental concern: the biodiversity strategy. Considering the ambiguity of the ecological term and the multiple interpretations that consumers make of it [16], it might be convenient to focus the awareness efforts on a new dimension which is more concrete and easy to interpret by consumers. In this context, the argument we support is that biodiversity is a term less ambiguous in its interpretation and easier for the consumer to understand. Thus, biodiversity is defined as the degree of variation of life (genetic, species and ecosystem changes) within a geographical area that shares climate, flora and fauna [55]. In short, its meaning is associated with the diversity of life; that is, the diversity of plant and animal species that live in a given place.

On the other hand, among the main environmental problems, the loss of biodiversity is one of the most relevant, being considered one of the key indicators of environmental improvement [55]. In this sense, biodiversity is considered a critical variable for the functioning of the ecosystem services and it is directly related to the economic, social and environmental components of sustainability [56]. These arguments are the foundations for sustaining the idea that biodiversity is probably the main 
environmental dimension of sustainability, and the most important indicator of the health of the planet $[57,58]$.

Under the assumptions that consumers are susceptive to arguments and messages related to biodiversity, the goals which we pursue with this study are to explore biodiversity as a new dimension of environmental concern, to know its implications and to establish a typology of consumers based on their degree of concern regarding biodiversity.

Furthermore, according to the cultural differences detected in pro-environmental consumer behavior in the literature [59-62], we also explore the question of the influence of different countries and cultures in the way they experience the biodiversity.

After reviewing the literature and defining the goals, the Materials and Methods section explains the research method used and the characteristics of the sample. The results obtained are then presented and interpreted according to the literature. Finally, the main conclusions are presented as well as the theoretical and practical implications that are derived, both at a general level and in the case of olive oils, the area in which the research is carried out.

\section{Materials and Methods}

In this work, we adopted a quantitative approach. The classification of consumers concerned by biodiversity was carried out in four European countries for the case of olive oil. These markets have the advantage of being interesting for themselves. The reason for which these countries have been chosen is due to their distinct level of olive oil consumption and because they hold different levels of environmental concern. We find some differences between them and, consequently, they can serve, a priori, as guidance of what could happen in others. Thus, the selected countries are Spain, Germany, the United Kingdom and Denmark.

In each of these four countries, we have conducted an Online-CAWI survey of 800 individuals randomly selected in a consumer panel, who had to meet two prerequisites to be included in the study: to be involved or interested in biodiversity and to be consumers of olive oils. The four surveys were carried out by a market research group (Grupo Análisis e Investigación) which offers a consumer panel for surveys (a permanent sample in which people selected in each survey receive stimuli for answer surveys as points that can be exchange for gifts). It was specified that they should have bought the product in the last year and that they had to be very or quite concerned about the conservation of nature. On the other hand, several quotas were established in each country, so that the number of surveys was balanced according to the gender and age- -half, from 25 to 40 and, the other half, from 41 to 65 . Likewise, the number of highly educated individuals was restricted to a maximum of 350 interviews per country and the number of unemployed interviewees or those exclusively dedicated to home care limited to no more of 160 . In summary, restricted random sampling was conducted with a total of 3200 interviews and a maximum sample error, approximate as SRS of $+3.52 \%$ for global percentages per country $\mathrm{p}=\mathrm{q}=0.5 ; \mathrm{K}=2$ (Table 1 ).

To achieve the objective, we carried out a cluster analysis including variables related to the concern about biodiversity, the subjective knowledge, the willingness to pay, the greater demand to the government to allocate more resources, as well as socio-demographic variables. All the items with which we worked are included in a larger questionnaire developed for a research project, whose aim is the study of the main characteristics of the segment of consumers who are potentially prone to the acquisition of sustainable olive oils that preserve biodiversity.

Specifically, the concern about biodiversity was studied through 9 items. These were developed based on information obtained through 4 focus groups in a previous research. The purpose of this prior research was to study what biodiversity is, what it means and how it is interpreted; especially in comparison with related concepts such as environmental preservation or ecology. Two focus groups were conducted with ordinary young people and another two with young people involved in active nature conservation behaviors (the results of this qualitative research are not yet published.). 
The 9 items reflected expressions or ideas that allowed us to determine a successive gradation regarding the degree of concern for the biodiversity, ranging from "I am not concerned" (EC1-EC5) to "I adopt an active behavior and influence others" (EC6-EC9), where the response options are "agree", "disagree" and "have no concrete opinion". Five of these items were written in the negative sense (EC1-EC5), so they were reconverted to homogenize the analysis (Table 2).

The socio-demographic variables included in the analysis were age, gender, level of education and income level of the family unit. In addition, we analyzed other ecological variables such as subjective knowledge or the level of social concern about nature-related issues. Finally, the predisposition to pay and the political demand to the government were studied to allocate more resources to protecting biodiversity.

Table 1. Sample.

\begin{tabular}{cc}
\hline & Demographic Profile \\
\hline & Country \\
\hline Spain & 800 \\
Germany & 800 \\
United Kingdom & 800 \\
Denmark & 800 \\
\hline & Gender \\
\hline Male & 1600 (400 per country) \\
Female & 1600 (400 per country) \\
\hline 25 to 40 years & Age \\
Older than 40 years & 1600 (400 per country) \\
\hline & 1600 (400 per country) \\
\hline No higher education & Level of Education \\
With higher education & Between 300 and 350 max. (per country) \\
\hline
\end{tabular}

Scope: international (Spain, Germany, United Kingdom, Denmark); target: urban buyers of olive oil, aged 25-65 years; type of interview: Online CAWI using a structured questionnaire; sample size: 3200 valid cases (800 per country); type of sample: random restricted by age, gender and education level; sample error: SRS of $+3.52 \%$ for global percentages per country $\mathrm{p}=\mathrm{q}=0.5 ; \mathrm{K}=2$.

Table 2. Items used in the cluster analysis.

\begin{tabular}{cc}
\hline Variable & Description \\
\hline EC1 & Claims about threats to biodiversity loss are exaggerated \\
EC2 & Biodiversity is not a major problem for me \\
EC3 & I find it difficult to know if my way of life is good or bad for biodiversity \\
EC4 & It is difficult for an individual to do something for biodiversity \\
EC5 & There is no point in doing everything I can for biodiversity if others do not \\
EC6 & I do what is good for biodiversity, even if it costs me more money or time \\
EC7 & I usually buy products that foster biodiversity \\
EC8 & I try to convince others to look after biodiversity \\
EC9 & I actively participate in defense of biodiversity (associations, demonstrations, social networks, \\
& donation to environmental groups) \\
\hline
\end{tabular}

The IBM's software SPSS has been used for the tabulation and analysis of data. In order to analyze the existent similarities or resemblances of the survey respondents, we made use of the case clustering multivariate technique (K-medians clustering). The technique known as discriminant analysis has been applied to validate every case cluster obtained in the cluster analysis phase. We have applied statistics and association measures based on the clusters or segments obtained, which provide the required information to study the possible patterns of association between the variables in order 
to analyze significant differences between these sample clusters. Specifically, the relation between nominal variables has been assessed by using the chi-squared test of independence; whilst the relation between ordinal and nominal variables has been tested by using Kruskal-Wallis and Mann-Whitney U's tests.

\section{Results and Discussion}

The aim of the research is to establish a typology of consumers based on their level of biodiversity concern. A non-hierarchical cluster analysis was carried out to identify similar groups as well as to determine their traits. Considering the criteria of maximizing the variance between typologies and minimizing the variance within any of them, the best approach that meets all the criteria is the one that defines four clusters or segments. To do so, the Kruskal-Wallis test was carried out for three, four and five clusters, resulting in the highlight of the candidature which holds four clusters as the one that returns the highest value for the statistical test (the advantage of using the Kruskal-Wallis test instead of the statistical $\mathrm{F}$ from ANOVA is that it is not required to consider the assumptions of normality and equality of variances for the different variables).

Table 3 shows the characterization of the clusters based on the averages of the nine items, the aim of which is to measure the degree of biodiversity concern. The H statistic from Kruskal-Wallis allows us to prove that the averages compared are not the same for the different obtained clusters; however, it is not possible to specify where those differences are to be found. In order to discover which average differs from the others, the Mann-Whitney U statistic was used.

Table 3. Characterization of the clusters based on the level of concern towards biodiversity.

\begin{tabular}{|c|c|c|c|c|c|}
\hline \multirow{2}{*}{ Items } & \multicolumn{4}{|c|}{ Consumers Clusters (Means) } & \multirow{2}{*}{$\begin{array}{c}\text { H-Kruskal Wallis } \\
\chi^{2}, p\end{array}$} \\
\hline & Non-Concerned & Passives & Actives & Influencers & \\
\hline $\begin{array}{c}\text { Claims about threats to biodiversity loss are } \\
\text { exaggerated }\end{array}$ & $1.45\left(^{*}\right)$ & 1.84 & $1.84\left({ }^{*}\right)$ & $1.87\left(^{*}\right)$ & $\begin{array}{c}802.15 \\
0.000\end{array}$ \\
\hline Biodiversity is not a major problem for me & $1.48\left(^{*}\right)$ & $1.82(*)$ & $1.86\left(^{*}\right)$ & $1.91(*)$ & $\begin{array}{c}871.39 \\
0.000\end{array}$ \\
\hline $\begin{array}{l}\text { I find it difficult to know if my way of life is good } \\
\text { or bad for biodiversity }\end{array}$ & $1.35\left(^{*}\right)$ & 1.38 & 1.40 & $1.74\left(^{*}\right)$ & $\begin{array}{c}484.55 \\
0.000\end{array}$ \\
\hline $\begin{array}{l}\text { It is difficult for an individual to do something } \\
\text { for biodiversity }\end{array}$ & $1.39\left(^{*}\right)$ & $1.63(*)$ & $1.06\left(^{*}\right)$ & $1.97\left({ }^{*}\right)$ & $\begin{array}{c}1906.06 \\
0.000\end{array}$ \\
\hline $\begin{array}{l}\text { There is no point in doing everything I can for } \\
\text { biodiversity if others do not }\end{array}$ & $1.28\left(^{*}\right)$ & 1.93 & $1.82\left(^{*}\right)$ & $1.91\left(^{*}\right)$ & $\begin{array}{c}1570.46 \\
0.000\end{array}$ \\
\hline $\begin{array}{l}\text { I do what is good for biodiversity, even if it costs } \\
\text { me more money or time }\end{array}$ & $1.51\left(^{*}\right)$ & $1.71\left(^{*}\right)$ & $1.23\left({ }^{*}\right)$ & $1.11\left(^{*}\right)$ & $\begin{array}{c}1218.85 \\
0.000\end{array}$ \\
\hline I usually buy products that foster biodiversity & $1.53(*)$ & $1.74\left(^{*}\right)$ & $1.18\left(^{*}\right)$ & $1.07\left(^{*}\right)$ & $\begin{array}{c}1555.69 \\
0.000\end{array}$ \\
\hline I try to convince others to look after biodiversity & $1.55\left(^{*}\right)$ & $1.79\left(^{*}\right)$ & $1.23(*)$ & $1.09\left(^{*}\right)$ & $\begin{array}{c}1484.60 \\
0.000\end{array}$ \\
\hline $\begin{array}{l}\text { I actively participate in defense of biodiversity } \\
\text { (associations, demonstrations, social networks, } \\
\text { donation to environmental groups) }\end{array}$ & $1.62(*)$ & $1.92(*)$ & $1.66\left(^{*}\right)$ & $1.48\left(^{*}\right)$ & $\begin{array}{c}546.95 \\
0.000\end{array}$ \\
\hline
\end{tabular}

Note: the numbers of the cells are means of the scale 1 (agree), 1.5 (have no concrete opinion) and 2 (disagree);

$\left(^{*}\right)$ The values present significant differences in three of four of the means clusters. In order to be able to test for the significant differences between the different means the Mann-Whitney U tests was applied.

The analysis identifies four consumer clusters or segments. The first one is made up of $20.06 \%$ of the consumers and gathers those who do not have an opinion regarding biodiversity. The segment is defined as "not concerned" with this issue. The second represents $35.81 \%$ and it gathers consumers who have a "passive interest" on biodiversity. For this group, biodiversity is a major environmental problem, although they believe that it is hard to adopt behaviors that contribute to its improvement. The third group represents $22.13 \%$ of the sample, and it is a segment of consumers with an "active" biodiversity concern that is reflected in the purchase of products that favor biodiversity, even though this entails a greater effort in terms of time and price. Finally, the fourth group is made up of $22 \%$ of consumers. It is a group with a proactive behavior in favor of biodiversity, which not only buys 
products that contribute to the improvement of biodiversity, but also participates in nature conservation actions, becoming defenders of biodiversity. This segment has been called "influencers".

The analysis results were validated through a discriminant analysis in order to find out the percentage of subjects who are correctly assigned. Table 4 shows a contingency table between the individuals belonging to each cluster and those who are correctly classified according to this analysis. According to it, the classification of four groups is valid, since $93.9 \%$ of the cases are correctly grouped.

Table 4. Discriminant analysis synthesis.

\begin{tabular}{cccccc}
\hline & \multicolumn{3}{c}{ Predicted Membership Clusters } & \multirow{2}{*}{ Total } \\
\cline { 2 - 5 } & Not Concerned & Passives & Actives & Influencers & \\
\hline Not concerned & 642 & Count & & & \\
Passives & 20 & 680 & 35 & 31 & 766 \\
Actives & 25 & 10 & 630 & 7 & 672 \\
Influencers & 20 & 11 & 10 & 1053 & 1094 \\
\hline & \multicolumn{5}{c}{ Percentage } \\
Not concerned & 96.1 & 2.8 & 0.4 & 0.6 & 100 \\
Passives & 2.6 & 88.8 & 4.6 & 4.0 & 100 \\
Actives & 3.7 & 1.5 & 93.8 & 1.0 & 100 \\
Influencers & 1.8 & 1.0 & 0.9 & 96.3 & 100 \\
\hline
\end{tabular}

These four clusters or segments allow us to classify sustainable consumers according to their level of involvement or concern with biodiversity. These results could be compared with the classification of ecological consumers proposed by Alvarez-Gonzalez et al. [33] in which they distinguish three categories of consumers according to different variables, among them, the degree of environmental concern distinguishing between highly concerned, concerned and less concerned consumers. However, environmental concern is a broader concept than a concern for the biodiversity and the present work is the first approach to the study of the biodiversity.

The definition of these four segments establishes different stages or levels of consumer concern with biodiversity, starting from a low to high concern. Thus, the non-concerned segment responds to an initial stage where the consumer does not show any interest at all in the biodiversity, whereas the influencer segment represents a stage where the level of consumer involvement with biodiversity concerns translates not only into the purchase of biodiversity-friendly products but also into the support of the trend through the development of initiatives that contributes to raising awareness in our society. These results are in line with previous studies in which evidence of a positive relationship between environmental concern and the willingness to buy green products was found [29-31,36-40].

The distribution of each segment, classified by country, is shown in Table 5. At a global level, 55 percent of the consumers are classified within the active and influencer segments.

Table 5. Distributions of the segments depending on the country.

\begin{tabular}{|c|c|c|c|c|c|}
\hline \multirow{2}{*}{ Variables } & \multicolumn{4}{|c|}{ Segments (Percentage) } & \multirow{2}{*}{ Test } \\
\hline & Not Concerned & Passives & Actives & Influencers & \\
\hline Countries & 20.9 & 23.9 & 21.0 & 34.2 & $\begin{array}{c}209.204^{* * *} \\
V=0.148\end{array}$ \\
\hline Denmark & 15.3 & 26.4 & 29.3 & 29.1 & \\
\hline Germany & 23.5 & 17.1 & 26.1 & 33.3 & \\
\hline United Kingdom & 26.6 & 29.6 & 17.9 & 25.9 & \\
\hline Spain & 18.1 & 22.6 & 10.8 & 48.5 & \\
\hline
\end{tabular}


There are significant differences by country between the different segments. The weight of the active and influencers segments is important in all countries. However, the weight of the non-concerned segment in Germany and the United Kingdom is noteworthy, as is the weight of the passive segment in Denmark, the United Kingdom and Spain. The importance of the influencers segment in Spain is also surprising.

On the other hand, the existence of significant differences between the segments has been analyzed in terms of ecological variables such as subjective knowledge or social concern, as well as the willingness to pay for products that preserve biodiversity and the greater demand on governments to allocate more resources to protecting biodiversity (Table 6).

Table 6. Characterization of segments according to ecological variables and willingness to pay.

\begin{tabular}{|c|c|c|c|c|c|}
\hline \multirow{2}{*}{ Variables } & \multicolumn{4}{|c|}{ Segments } & \multirow{2}{*}{ Test H Kruskal Wallis } \\
\hline & Not Concerned & Passives & Actives & Influencers & \\
\hline \multicolumn{6}{|c|}{ Subjective Knowledge } \\
\hline Average & 3.38 & 3.42 & 3.67 & 3.87 & $\begin{array}{c}264.295 \\
p=0.000\end{array}$ \\
\hline Denmark & 3.20 & 3.42 & 3.56 & 3.83 & \\
\hline Germany & 3.20 & 3.34 & 3.72 & 3.80 & \\
\hline United Kingdom & 3.56 & 3.64 & 3.83 & 4.04 & \\
\hline Spain & 3.20 & 3.34 & 3.72 & 3.80 & \\
\hline \multicolumn{6}{|c|}{ Social Awareness } \\
\hline Average & 1.89 & 2.00 & 2.00 & 2.02 & $\begin{array}{c}21.197 \\
p=0.000\end{array}$ \\
\hline Denmark & 2.00 & 2.06 & 2.03 & 2.12 & \\
\hline Germany & 2.01 & 2.01 & 2.07 & 2.05 & \\
\hline United Kingdom & 1.76 & 1.90 & 1.80 & 1.87 & \\
\hline Spain & 1.85 & 2.07 & 2.03 & 2.01 & \\
\hline \multicolumn{6}{|c|}{ Higher Prices } \\
\hline Average & 3.13 & 3.19 & 3.63 & 3.88 & $\begin{array}{c}365.887 \\
p=0.000\end{array}$ \\
\hline Denmark & 2.95 & 3.11 & 3.60 & 3.91 & \\
\hline Germany & 3.16 & 3.48 & 3.78 & 4.10 & \\
\hline United Kingdom & 3.13 & 3.26 & 3.62 & 3.97 & \\
\hline Spain & 3.25 & 2.97 & 3.35 & 3.67 & \\
\hline \multicolumn{6}{|c|}{ Political Exigence } \\
\hline Average & 3.80 & 4.13 & 4.39 & 4.62 & $\begin{array}{c}512.326 \\
p=0.000\end{array}$ \\
\hline Denmark & 3.49 & 4.03 & 4.38 & 4.64 & \\
\hline Germany & 3.85 & 4.23 & 4.42 & 4.54 & \\
\hline United Kingdom & 3.77 & 4.14 & 4.34 & 4.70 & \\
\hline Spain & 4.04 & 4.18 & 4.44 & 4.63 & \\
\hline
\end{tabular}

Subjective knowledge was measured on a scale of 1 to 5 (uninformed to highly informed), in a similar way to that which is done in the literature $[63,64]$. In this sense, the influencers segment is the one with the highest average score, i.e., the one that is considered as having the greatest knowledge about nature-related issues. The average score increases starting from the segment of not concerned to the segment of influencers, which means that the greater the subjective knowledge, the greater the concern for biodiversity. This relationship is also reflected in the country analysis.

The level of social concern about nature-related issues was assessed using a scale of 1 to 3 (with interest and concern, with interest but not enough concern, without interest). The analysis carried out shows that there are no major differences with respect to this variable, with an average of 2, meaning that consumers think that society is not sufficiently concerned about problems related to nature. 
The opinion or attitude to pay higher prices for biodiversity-friendly products was measured using a scale of 1 to 5 (not at all in favor to very in favor). The analysis shows that the influencer segment is most willing to pay higher prices for biodiversity-friendly products, with a gradual progression from the non-concerned segment to the influencer segment. The relationship between the level of concern about biodiversity and the willingness to pay is also reflected in the country analysis, in which the average willingness to pay increases from the non-concerned segment to the influencers. It is also interesting to highlight that in almost all segments, the countries that are willing to pay the highest premium are Germany and the United Kingdom. Likewise, Spain is the country with the lowest predisposition to pay for products that preserve biodiversity. Despite the fact that overpricing is one of the main reasons given in the literature related to not buying green food products in general [65-67], the results obtained show that the greater the level of environmental concern, the greater the willingness to pay higher prices.

The political demand to the government to allocate more resources to biodiversity was measured on a scale of 1 to 5 (not at all in favor to very much in favor). In general, the average scores given by the segments in favor of a greater contribution of resources to preserve biodiversity are high. The segment most likely to demand resources from governments is the influencers one, with a relationship between greater concern for biodiversity and a willingness to demand more resources to preserve it. By country, this relationship is also maintained so that the average scores increase from the segment of not concerned to the segment of influencers. In the not-concerned segment, Spain is the country with the highest average scores in favor of greater political demand. In the influencers segment, the average scores are high in all countries, with the United Kingdom slightly higher.

Regarding the characterization of the segments according to the socio-demographic profile, there are significant differences, although they are small (Table 7). Thus, in the not-concerned segment, the percentage of men is slightly higher. The same occurs with the passive and influencer segments, where the percentage of women is slightly higher. In terms of age, the percentage of younger consumers is higher in the non-concerned and passive segments. However, in the segment of influencers, the percentage of consumers over 41 is greater. Finally, in the segment of not concerned, the percentage of consumers with secondary education is greater. However, in the rest of the segments, there are no differences in terms of the academic training variable.

Table 7. Socio-demographic profile of consumers concerned about biodiversity.

\begin{tabular}{|c|c|c|c|c|c|c|c|}
\hline \multirow{2}{*}{ Variables } & \multirow{2}{*}{ Categories } & \multicolumn{4}{|c|}{ Clusters (Percentage) } & \multirow{2}{*}{ Total } & \multirow{2}{*}{ Test } \\
\hline & & Not Concerned & Passives & Actives & Influencers & & \\
\hline \multirow{2}{*}{ Sex } & Men & 53.6 & 48.0 & 51.0 & 47.5 & 49.7 & \multirow{2}{*}{$\begin{array}{l}\chi^{2}: 7.430^{*} \\
V=0.048\end{array}$} \\
\hline & Women & 46.4 & 52.0 & 49.0 & 52.5 & 50.3 & \\
\hline \multirow[t]{2}{*}{ Age } & $\begin{array}{l}\text { Between } \\
25 \text { to } 40\end{array}$ & 54.6 & 52.2 & 49.3 & 44.4 & 49.4 & \multirow{2}{*}{$\begin{array}{l}\text { Kruskal-Wallis: } \\
20.609 ; p=0.000\end{array}$} \\
\hline & Over 40 & 45.4 & 47.8 & 50.7 & 55.6 & 50.6 & \\
\hline \multirow{4}{*}{ Educational level } & $\begin{array}{l}\text { Without } \\
\text { studies }\end{array}$ & 0.4 & 0.1 & 0.2 & 0.3 & 0.3 & \multirow{4}{*}{$\begin{array}{l}\text { Kruskal-Wallis: } \\
10.431 ; p=0.015\end{array}$} \\
\hline & $\begin{array}{c}\text { Primary } \\
\text { education }\end{array}$ & 7.2 & 8.3 & 5.8 & 5.1 & 6.4 & \\
\hline & $\begin{array}{l}\text { Secondary } \\
\text { education }\end{array}$ & 50.6 & 45.2 & 45.1 & 47.0 & 46.7 & \\
\hline & $\begin{array}{l}\text { Higher } \\
\text { education }\end{array}$ & 41.8 & 46.3 & 49.0 & 47.7 & 46.6 & \\
\hline
\end{tabular}

Chi-Squared test to check value independence and Cramer's V value; $\alpha=$ level of significance. If $\alpha<0.1 *$.

Table 8 shows the analysis of the socio-demographic characterization by country. Thus, the slight predominance of men in the segment of not concerned and of women in the segment of influencers is maintained, except in Spain, where the percentage of men is higher than that of women. In Denmark and the United Kingdom, the weight of men is greater in the passive segment, with an opposite trend 
in Germany and Spain, where the percentage of women is greater. Also, in Germany and Spain, the percentage of men is higher in the active segment.

In relation to age, those under 40 predominate in the non-concerned and passive segments, except in the United Kingdom, where the percentage of consumers over 41 is higher in the passive segment. Similarly, the percentage of consumers over 41 is higher in the influencers segment in all countries. In the active segment, the percentage of young consumers is slightly higher in Denmark and Germany. However, the opposite is the case in the UK and Spain, where the percentage of consumers over 41 is higher.

The percentage of consumers with a secondary education is predominant in Germany and Spain, while the percentage of consumers with a university degree is higher in Denmark and the United Kingdom in all segments.

Lastly, the level of income in each country and its influence on the level of concern about biodiversity was analyzed with no significant differences between the segments. The results of the Kruskal-Wallis test are as follows: Spain $\left(\chi^{2}: 2.842 ; p=0.417\right)$, Germany $\left(\chi^{2}: 6.518 ; p=0.089\right)$, United Kingdom $\left(\chi^{2}: 0.709 ; p=0.871\right)$ and Denmark $\left(\chi^{2}: 7.033 ; p=0.071\right)$.

Table 8. Characterization of the consumer concerned about biodiversity by country.

\begin{tabular}{|c|c|c|c|c|c|c|c|c|c|}
\hline \multirow{2}{*}{ Countries } & \multirow{2}{*}{ Segments (Percentage) } & \multicolumn{2}{|c|}{ Sex } & \multicolumn{2}{|c|}{ Age } & \multicolumn{4}{|c|}{ Educational Level } \\
\hline & & $\mathbf{M}$ & $\mathbf{W}$ & 25 to 40 & Over 40 & WS & $\mathbf{P}$ & Se & $\mathbf{H}$ \\
\hline \multirow{4}{*}{ Denmark } & Not concerned & 53.3 & 46.7 & 59.0 & 41.0 & 1.6 & 11.5 & 38.5 & 48.4 \\
\hline & Passives & 53.6 & 46.4 & 52.6 & 47.4 & 0.9 & 11.4 & 37.0 & 50.7 \\
\hline & Actives & 49.1 & 50.9 & 51.7 & 48.3 & 0.4 & 15.0 & 28.2 & 56.4 \\
\hline & Influencers & 45.9 & 54.1 & 41.2 & 58.8 & 0.9 & 9.4 & 29.6 & 60.1 \\
\hline \multirow{4}{*}{ Germany } & Not concerned & 54.8 & 45.2 & 51.1 & 48.9 & 0.5 & 8.0 & 60.6 & 30.9 \\
\hline & Passives & 47.4 & 52.6 & 61.3 & 38.7 & - & 7.7 & 50.4 & 43.8 \\
\hline & Actives & 53.1 & 46.9 & 51.2 & 48.8 & - & 8.6 & 56.0 & 36.4 \\
\hline & Influencers & 45.5 & 54.5 & 42.5 & 57.5 & - & 5.8 & 52.3 & 39.1 \\
\hline \multirow{4}{*}{ United Kingdom } & Not concerned & 50.7 & 49.3 & 56.3 & 43.7 & - & 2.8 & 47.4 & 49.8 \\
\hline & Passives & 51.1 & 48.9 & 45.1 & 54.9 & - & 0.4 & 46.4 & 53.2 \\
\hline & Actives & 50.3 & 49.7 & 43.4 & 56.6 & - & - & 51.0 & 49.0 \\
\hline & Influencers & 42.5 & 57.5 & 44.9 & 55.1 & - & 1.0 & 32.4 & 66.7 \\
\hline \multirow{4}{*}{ Spain } & Not concerned & 56.6 & 43.4 & 53.1 & 46.9 & - & 9.0 & 52.4 & 38.6 \\
\hline & Passives & 38.1 & 61.9 & 54.1 & 45.9 & - & 3.3 & 56.9 & 39.8 \\
\hline & Actives & 52.3 & 47.7 & 47.7 & 52.3 & - & 5.8 & 55.8 & 38.4 \\
\hline & Influencers & 52.6 & 47.4 & 47.4 & 52.6 & - & 4.1 & 56.2 & 39.7 \\
\hline \multirow{4}{*}{ Total } & Not concerned & 53.6 & 46.4 & 54.6 & 45.4 & 0.4 & 7.2 & 50.6 & 41.8 \\
\hline & Passives & 48.0 & 52.0 & 52.2 & 47.8 & 0.3 & 5.1 & 47.0 & 47.7 \\
\hline & Actives & 51.0 & 49.0 & 49.3 & 50.7 & 0.1 & 8.3 & 45.2 & 46.3 \\
\hline & Influencers & 47.5 & 52.5 & 44.4 & 55.6 & 0.2 & 5.8 & 45.1 & 49.0 \\
\hline
\end{tabular}

\section{Conclusions}

This paper assesses the environmental concern from a new perspective of biodiversity as one of the key indicators of environmental improvement, and therefore the main dimension of sustainability. As a main conclusion, a typology of sustainable consumers has been identified according to their level of concern about biodiversity.

Specifically, four segments have been identified (not-concerned, passives, actives and influencers), shaping up a multilevel structure of increasing intensity with respect to the degree of consumers' concern about biodiversity. To summarize, these are different levels of intensity or involvement with biodiversity that represent a lesser or greater degree of commitment to the conservation of nature.

The analysis has highlighted the existence of significant differences between segments in terms of variables such as subjective knowledge, willingness to pay and greater demand for public resources allocated to preserving biodiversity. Slight significant differences have also been found between the segments in terms of geographical and socio-demographic variables. 
The results obtained can be very useful and have implications from both a theoretical and practical approach.

From a theoretical perspective and considering the slow growth of the demand for ecological products, the present work raises a new semantic-conceptual dimension. Based on the ambiguity in the interpretation (due to their breadth) of terms such as sustainability or ecology, for operational purposes of changing consumer behavior, it is proposed to focus communication strategies on a less ambiguous term, biodiversity. Considering that it is probably the main environmental dimension of sustainability and the main impact of human behavior on the earth, it is proposed to use it as a central element of awareness campaigns. This is consistent with the contributions of Vega et al. [14,68], who proposed the need to study the choice of terms given their effects on interpretation and attitude-forming processes. In short, we refer to the power of the word and biodiversity is a powerful word, easy to interpret, unambiguous and it is possible to measure the degree of concern that can be measured.

In this context, its measurement allows us to establish with some clarity the level at which the consumers are located, and the size and characteristics of each group, which can be used to establish the awareness strategies adapted to each country, deciding whether to emphasize one group or another. However, it should be noted that the concern for biodiversity constitutes a first approach to its study. Although the items are based on a previous qualitative research, it is possible to conduct other studies in other different cultural contexts that allow us to enter other dimensions or items into the scale, constituting a limitation of the work and a suggestion for future research.

The establishment of groups and levels of commitment of individuals to the environment is not new. Other works, such as that of Paswan et al. [69], have developed sequential models or degrees of pro-environmental behavior, distinguishing a commitment to support the environment from a commitment where nature conservation becomes a philosophy of life for the consumer.

However, these studies are not comparable with our research because they did not focus on environmental concern in general, nor on concern for biodiversity in particular, and because they did not attempt to characterize the consumer at each of the phases or levels that were identified, nor to quantify their size, which is fundamental to articulating effective awareness and persuasion strategies towards more sustainable behavior.

From a practical perspective, the identification of these segments is especially worthwhile for two reasons. Firstly, because it will allow the design of more effective communication strategies according to the level of commitment of consumers to biodiversity. Secondly, to quantify the size of each segment and analyze its attractiveness.

In the case of olive oils, the field in which the research has been carried out, the results also have important implications. Thus, olive oil is obtained from a humanized forest that shelters multiple species of animals and plants, being considered a strategic crop for the conservation of biodiversity in Europe. The identification of a new ecological variable, the concern for biodiversity, can be effective in segmenting the olive oil market and orienting consumers towards the consumption of olive oils that preserve the environment, which is fundamental to stimulate the demand for olive oils. Moreover, this would provide an important stimulus for farmers to maintain their olive tree plantations as well as the animal and plant species living in the olive grove, which could contribute to the development of a new model of exploitation of olive groves, aiming for sustainable practices in line with the new guidelines of the common agricultural policy (CAP).

Finally, although the results of the study are specifically oriented to olive oil, their possible extrapolation to other products should be considered.

Author Contributions: Conceptualization: E.M.M.-A. and M.G.-S.; methodology: E.M.M.-A., M.G.-S. and F.J.T.-R.; investigation: E.M.M.-A., M.G.-S. and F.J.T.-R.; resources: E.M.M.-A., M.G.-S. and F.J.T.-R.; writing-original draft preparation: E.M.M.-A., M.G.-S. and F.J.T.-R.; writing-review and editing: E.M.M.-A., M.G.-S. and F.J.T.-R.; supervision: E.M.M.-A., M.G.-S. and F.J.T.-R.; project administration: E.M.M.-A. and F.J.T.-R. All authors have read and agreed to the final version of the manuscript.

Funding: This research was funded by European Commission, grant number "LIFE14 NAT/ES/001094. Olive Alive. Toward the design and certification of olive groves reconciled with biodiversity". 
Acknowledgments: The authors would like to thank the anonymous reviewers for their valuable comments and suggestions to improve the quality of the paper.

Conflicts of Interest: The authors declare no conflict of interest.

\section{References}

1. Sarigöllü, E. Cross-country exploration of environmental attitudes. Environ. Behav. 2009, 41, 365-386. [CrossRef]

2. Kautish, P.; Sharma, R. Determinants of pro-environmental behavior and environmentally conscious consumer behavior: An empirical investigation from emerging market. Bus. Strategy Dev. 2020, 3, 112-127. [CrossRef]

3. Yazar, E.E.; Burucuoglu, M. Consumer attitude towards organic foods: A multigroup analysis across genders. Istanb. Bus. Res. 2019, 48, 176-196. [CrossRef]

4. Mostafa, M.M. Gender differences in Egyptian consumers' green purchase behavior: The effects of environmental knowledge, concern and attitude. Int. J. Consum. Stud. 2007, 31, 220-229. [CrossRef]

5. Dagher, G.K.; Itani, O.; Kassar, A.N. The impact of environment concern and attitude on green purchase behavior: Gender as the moderator. Contemp. Manag. Res. 2015, 11, 179-206. [CrossRef]

6. Stone, G.; Barnes, J.H.; Montgomery, C. ECOSCALE: A scale for the measurement of environmentally responsible consumers. Psych. Mark. 1995, 12, 595-612. [CrossRef]

7. Choi, D.; Johnson, K.K.P. Influences of environmental and hedonic motivations on intention to purchase green products: An extension of the theory of planned behavior. Sustain. Prod. Consum. 2019, 18, 145-155. [CrossRef]

8. Fujii, S. Environmental concern, attitude toward frugality, and ease of behavior as determinants of pro-environmental behavior intentions. J. Env. Psychol. 2006, 26, 262-268. [CrossRef]

9. Chen, C.C.; Chen, C.W.; Tung, Y.C. Exploring the consumer behavior of intention to purchase green products in belt and road countries: An empirical analysis. Sustainability 2018, 10, 854. [CrossRef]

10. Kim, Y.; Choi, S.M. Antecedents of green purchase behavior: An examination of collectivism, environmental concern, and PCE. Adv. Consum. Res. 2005, 32, 592-599.

11. Esmaeilpour, M.; Bahmiary, E. Investigating the impact of environmental attitude on the decision to purchase a green product with the mediating role of environmental concern and care for green products. Manag. Mark. Chall. Knowl. Soc. 2017, 12, 297-315. [CrossRef]

12. Roberts, J.A.; Bacon, D.R. Exploring the subtle relationships between environmental concern and ecologically conscious behavior. J. Bus. Res. 1997, 40, 79-89. [CrossRef]

13. Kim, Y. Understanding green purchase: The influence of collectivism, personal values and environmental attitudes, and the moderating effect of perceived consumer effectiveness. Seoul J. Bus. 2011, 17, 65-92.

14. Vega-Zamora, M.; Parras-Rosa, M.; Torres-Ruiz, F.J. Exploring the "Organic" attribute in the perception of iconic foods-The case of olive oil in Spain. Outlook Agric. 2013, 42, 243-247. [CrossRef]

15. Vega-Zamora, M.; Torres-Ruiz, F.J.; Murgado-Armenteros, E.M.; Parras-Rosa, M. A Powerful word: The influence of the term "Organic" on perceptions and beliefs concerning food. Int. Food Agribus. Manag. Rev. 2013, 16, 51-76.

16. Peano, C.; Merlino, V.M.; Sottile, F.; Borra, D.; Massaglia, S. Sustainability for food consumers: Which perception? Sustainability 2019, 11, 5955. [CrossRef]

17. Michaelidou, N.; Hassan, L.M. The role of health consciousness, food safety concern and ethical identity on attitudes and intentions towards organic food. Int. J. Consum. Stud. 2008, 32, 163-170. [CrossRef]

18. Yin, S.; Wu, L.; Du, L.; Chen, M. Consumers' purchase intention of organic food in China. J. Sci. Food Agric. 2010, 90, 1361-1367. [CrossRef]

19. Sreen, N.; Purbey, S.; Sadarangani, P. Impact of culture, behavior and gender on green purchase intention. J. Retail. Consum. Serv. 2018, 41, 177-189. [CrossRef]

20. Chan, R. Determinants of Chinese consumers' green purchase behavior. Psych. Mark. 2001, 18, $389-413$. [CrossRef]

21. Chan, R.Y.K.; Lau, L.B.Y. The effectiveness of environmental claims among Chinese consumers: Influences of claim type, country disposition and ecocentric orientation. J. Mark. Manag. 2004, 20, 273-319. [CrossRef] 
22. Gregory, G.D.; Munch, J.M.; Peterson, M. Attitude functions in consumer research: Comparing value-attitude relations in individualist and collectivist cultures. J. Bus. Res. 2002, 55, 933-942. [CrossRef]

23. Dean, M.; Raats, M.M.; Shepherd, R. Moral concerns and consumer choice of fresh and processed organic foods. J. Appl. Soc. Psychol. 2008, 38, 2088-2107. [CrossRef]

24. Arvola, A.; Vassallo, M.; Dean, M.; Lampila, P.; Saba, A.; Lahteenmaki, R. Predicting intentions to purchase organic food: The role of affective and moral attitudes in the theory of planned behavior. Appetite 2008, 50, 443-454. [CrossRef] [PubMed]

25. Honkanen, P.; Verplanken, B.; Olsen, S.O. Ethical values and motives driving organic food choice. J. Consum. Behav. 2006, 5, 420-430. [CrossRef]

26. Shaw, D.; Shui, E. An assessment of ethical obligation and self-identity in ethical consumer decision-making: A structural equation modelling approach. Int. J. Consum. Stud. 2002, 26, 286-293. [CrossRef]

27. Chan, A.; Wong, S.; Leung, P. Applying ethical concepts to the study of "Green" consumer behavior: An analysis of Chinese consumers' intentions to bring their own shopping bags. J. Bus. Ethics 2008, 79, 469-481. [CrossRef]

28. Crosby, L.A.; Gill, J.D.; Taylor, J.R. Consumer/voter behavior in the passage of the michigan container law. J. Mark. 1981, 45, 19-32. [CrossRef]

29. Aytekin, M.; Büyükahraz, G. The impact of between the environmental interest, concern and sensitivity level and on purchasing behavior of environmentally friendly product. Int. J. Bus. Econ. Dev. 2013, 1, 37-45.

30. Minton, A.P.; Rose, R.L. The effects of environmental concern on environmentally friendly consumer behavior: An exploratory study. J. Bus. Res. 1997, 40, 37-48. [CrossRef]

31. Datta, S.K. Pro-environmental concern influencing green buying: A study on Indian consumers. Int. J. Bus. Manag. 2011, 6, 124-133.

32. Diamantopoulos, A.; Schlegelmilch, B.B.; Sinkovics, R.R.; Bohlen, G.M. Can socio-demographics still play a role in profiling green consumers? A review of the evidence and an empirical investigation. J. Bus. Res. 2003, 56, 465-480. [CrossRef]

33. Álvarez-González, P.; López-Miguens, M.J.; González-Vázquez, E. El perfil del consumidor ecológico en España. Esic Mark. Econ. Bus. J. 2015, 46, 269-297.

34. Dunlap, R.; Van Liere, K.; Mertig, A.; Jones, R. New trends in measuring environmental attitudes: Measuring endorsement of the new ecological paradigm: A revised NEP scale. J. Soc. Issues 2000, 56, 425-442. [CrossRef]

35. Arroyo-López, P.; Carrete, L.; Trujillo, A. Segmentación de individuos con base en su perfil demográfico, conocimiento, actitudes y conducta de reciclaje en una economía emergente. Panor. Socioecon. 2013, 44, $26-44$.

36. Hartmann, P.; Apaolaza-Ibáñez, V. Consumer attitude and purchase intention toward green energy brands: The roles of psychological benefits and environmental concern. J. Bus. Res. 2012, 65, 1254-1263. [CrossRef]

37. Newton, J.D.; Tsarenko, Y.; Ferraro, C.; Sands, S. Environmental concern and environmental purchase intentions: The mediating role of learning strategy. J. Bus. Res. 2015, 68, 1974-1981. [CrossRef]

38. Rhead, R.; Elliot, M.; Upham, P. Assessing the structure of UK environmental concern and its association with pro-environmental behavior. J. Environ. Psychol. 2015, 43, 175-183. [CrossRef]

39. Paul, J.; Modi, A.; Patel, J. Predicting green product consumption using theory of planned behavior and reasoned action. J. Retail. Consum. Serv. 2016, 29, 123-134. [CrossRef]

40. Li, G.; Li, W.; Jin, Z.; Wang, Z. "Influence of environmental concern and knowledge on households" willingness to purchase energy-efficient appliances: A case study in Shanxi, China. Sustainability 2019, 11, 1073. [CrossRef]

41. Prentice, C.; Chen, J.; Wang, X. The influence of product and personal attributes on organic food marketing. J. Retail. Consum. Serv. 2017, 46, 70-78. [CrossRef]

42. Smith, S.; Paladino, A. Eating clean and green? Investigating consumer motivations towards the purchase of organic food. Australas. Mark. J. 2010, 18, 93-104. [CrossRef]

43. Magnusson, M.K.; Arvola, A.; Koivisto, U.K.; Aberg, L.; Sjödén, P.O. Choice of organic foods is related to perceived consequences for human health and to environmentally friendly behavior. Appetite 2003, 40, 109-117. [CrossRef]

44. Yadav, R.; Pathak, G.S. Intention to purchase organic food among young consumers: Evidences from a developing nation. Appetite 2016, 96, 122-128. [CrossRef] [PubMed] 
45. Kriwy, P.; Mecking, R.A. Health and environmental consciousness, costs of behavior and the purchase of organic food. Int. J. Consum. Stud. 2012, 36, 30-37. [CrossRef]

46. Ting, C.T.; Chi-Ming, H.; Chang, H.P.; Chen, H.S. Environmental consciousness and green customer behavior: The moderating roles of incentive mechanisms. Sustainability 2019, 11, 819. [CrossRef]

47. Chen, M.F.; Tung, P.-J. Developing an extended theory of planned behavior model to predict consumers' intention to visit green hotels. Int. J. Hosp. Manag. 2014, 36, 221-230. [CrossRef]

48. Sang, Y.N.; Bekhet, H.A. Modelling electric vehicle usage intentions: An empirical study in Malaysia. J. Clean. Prod. 2015, 92, 75-83. [CrossRef]

49. Kalafatis, S.P.; Pollard, M.; East, R.; Tsogas, M.H. Green marketing and Ajzen's theory of planned behavior: A cross-market examination. J. Consum. Mark. 1999, 16, 441-460. [CrossRef]

50. Clark, C.F.; Kotchen, M.J.; Moore, M.R. Internal and external influences on pro-environmental behavior: Participation in a green electricity program. J. Environ. Psychol. 2003, 23, 237-246. [CrossRef]

51. Urban, J.; Scasny, M. Exploring domestic energy-saving: The role of environmental concern and background variables. Energy Policy 2012, 47, 69-80. [CrossRef]

52. Claudy, M.C.; Peterson, M.; O’Driscoll, A. Understanding the attitude-behavior gap for renewable energy systems using behavioral reasoning theory. J. Macromarketing 2013, 33, 273-287. [CrossRef]

53. Pickett-Baker, J.; Ozaki, R. Pro-environmental products: Marketing influence on consumer purchase decision. J. Consum. Mark. 2008, 25, 281-293. [CrossRef]

54. Malik, M.; Nawaz Mir, F.; Hussain, S.; Hyder, S.; Anwar, A.; Khan, Z.; Nawab, N.; Shah, S.; Waseem, M. Contradictory results on environmental concern while re-visiting green purchase awareness and behavior. Asia Pac. J. Innov. Entrep. 2019, 13, 17-28. [CrossRef]

55. Hooper, D.U.; Adair, E.C.; Cardinale, B.J.; Byrnes, J.E.K.; Hungate, B.A.; Matulich, K.L.; O'Connor, M.I. A global synthesis reveals biodiversity loss as a major driver of ecosystem change. Nature 2012, 486, 105-108. [CrossRef]

56. Niesenbaum, R.A. The integration of conservation, biodiversity and sustainability. Sustainability 2019, 11, 4676. [CrossRef]

57. Bradley, J.; Cardinale, J.; Duffy, E.; Gonzalez, A.; Hooper, D.U.; Perrings, C.; Venail, P.; Narwani, A.; Mace, G.M.; Tilman, D.; et al. Biodiversity loss and its impact on humanity. Nature 2012, 486, 59-67. [CrossRef]

58. Blicharska, M.; Smithers, R.J.; Mikusiński, G.; Rönnbäck, P.; Harrison, P.A.; Nilsson, M.; Sutherland, W.J. Biodiversity's contributions to sustainable development. Nat. Sustain. 2019, 2, 1083-1093. [CrossRef]

59. Bechtel, R.B.; Verdugo, V.C.; Pinheiro, J.Q. Environmental belief systems: United States, Brazil, and Mexico. J. Cross Cult. Psychol. 1999, 30, 122-128. [CrossRef]

60. Cordano, M.; Welkomer, S.; Scherer, R.F.; Pradenas, N.; Parada, V. Understanding cultural differences in the antecedents of pro-environmental behavior: A comparative analysis of business students in the United State and Chile. J. Environ. Educ. 2010, 41, 224-238. [CrossRef]

61. Mintz, K.K.; Henn, L.; Park, J.; Kurman, J. What predicts household waste management behaviors? Culture and type of behavior as moderators. Resour. Conserv. Recycl. 2019, 145, 11-18. [CrossRef]

62. Higueras-Castillo, E.; Munoz-Leiva, F.; Liebana-Cabanillas, F.J. An examination of attributes and barriers to adopt biomass and solar technology. A cross-cultural approach. J. Environ. Manag. 2019, 236, 639-648. [CrossRef] [PubMed]

63. Flynn, L.R.; Goldsmith, R.E. A short, reliable measure of subjective knowledge. J. Bus. Res. 1999, 46, 57-66. [CrossRef]

64. Perrouty, J.P.; d'Hauteville, F.; Lockshin, L. The influence of wine attributes on region of origin equity: An analysis of the moderating effect of consumer's perceived expertise. Agribusiness 2006, 22, 323-341. [CrossRef]

65. Parras-Rosa, M.; Vega-Zamora, M.; Gutiérrez Salcedo, M. El sobreprecio del aceite de oliva ecológico frente al del convencional a nivel minorista, como factor explicativo de su escasa cuota de ventas en España. Rev. Estud. Agrosoc. Pesq. 2011, 229, 145-160.

66. Marian, L.; Chrysochou, P.; Krystallis, A.; Thøgersen, J. The role of price as a product attribute in the organic food context: An exploration based on actual purchase data. Food Qual. Prefer. 2014, 37, 52-60. [CrossRef]

67. Bryła, P. Organic food consumption in Poland: Motives and barriers. Appetite 2016, 105, 737-746. [CrossRef] 
68. Vega-Zamora, M.; Torres-Ruiz, F.J.; Murgado-Armenteros, E.M.; Parras-Rosa, M. Organic as a heuristic cue what spanish consumers mean by organic foods. Psychol. Mark. 2014, 31, 349-359. [CrossRef]

69. Paswan, A.; Guzmán, F.; Lewin, J. Attitudinal determinants of environmentally sustainable behavior. J. Consum. Mark. 2017, 34, 414-426. [CrossRef] 